\title{
PENGARUH LOGO BARU PT. TELKOM, TbK TERHADAP CITRA PERUSAHAAN
}

\author{
Febriansyah, Nuzul Inas Nabila \\ Fakultas Ekonomi Institut Teknologi dan Bisnis Kalbis \\ E-mail:febri08@yahoo.com dan nuzulinasnabilaa@gmail.com
}

\begin{abstract}
This study aimed to determine to what extent rebranding had effect on corporate reputation. Through the implementation of quantitative research design, this project involved Telkom customers of Bandar Lampung as population where the sampling technique applied was non-probability sampling and purposive sampling approach. The research instruments were questionnaires which were handed out to 100 customers of Telkom Bandar Lampung during May 2013 period. Afterward, the data were analyzed using simple regression analysis. The results showed the value of $R$ square of company rebranding was 0.235 which indicated that the contribution $X$ variable (rebranding) played significant role in influencing each additional of $Y$ variable at $23.5 \%$ for corporate reputation while $76.5 \%$ were influenced by other factors. Further, hypothesis test results signified that t-test 5,486 was greater (>) than t-table 1,984 so that it can be concluded that rebranding had significantly affect Telkom Ltd. corporate reputation in Bandar Lampung.
\end{abstract}

Keywords: Corporate reputation, Identity, Logo

\begin{abstract}
Abstrak
Penelitian ini bertujuan untuk mengetahui sejauh mana logo baru mempengaruhi citra perusahaan. Penelitian ini menggunakan pendekatan kuantitatif. Populasi yang digunakan dalam penelitian ini adalah orang-orang di Bandar Lampung yang menggunakan layanan telkom. Pengambilan sampel menggunakan non-probability sampling dengan pendekatan purposive sampling. Penelitian ini menggunakan kuesioner yang diberikan kepada 100 pelanggan Telkom Bandar Lampung periode cabang Mei 2013. Kemudian data akan dianalisis dengan menggunakan analisis regresi sederhana. Hasil analisis data yang diperoleh pada pengaruh perubahan citra logo perusahaan $R$ Square sebesar 0.235 ini berarti bahwa kontribusi variabel $x$ (perubahan logo) berperan dalam mempengaruhi setiap tambahan variabel y $23,5 \%$ dari perusahaan gambar dan $76.5 \%$ sisanya dipengaruhi oleh faktor lain.. Uji hipotesis menunjukkan bahwa thitung ttabel lebih besar dari 5,486> 1,984 sarana untuk mengubah logo (rebranding) berpengaruh secara signifikan terhadap citra perusahaan di PT Telkom di Bandar Lampung.
\end{abstract}

Kata Kunci: Citra Perusahaan, Identitas, Logo

Perkembangan teknologidan informasi yang semakin canggih seperti sekarang ini, menjanjikan suatu peluang dan tantangan bisnis baru bagiperusahaan yang beroperasi di Indo- nesia, keadaan tersebut memunculkan persaingan yang semakin ketat baik antar perusahaan domestik maupun dengan perusahaan asing. Salah satu asset untuk mencapai 
keadaan tersebut adalah merek. Menurut Surachman (2008:14) Merek merupakan sebuah nama atau simbol (seperti logo, merek dagang, desain kemasan, dan sebagainya) yang dibuat untuk membedakan satu produk dengan produk lainnya. Salah satu elemen merek yang mampu memberikan kontribusi yang positif dalam penciptaan merek yang ideal yaitu logo dan simbol (Kotler, 2002:460).

Logo dan simbol merupakan seperangkat gambar atau huruf yang diciptakan untuk mengindikasikan keorisinilan, kepemilikan ataupunasosiasi. Walaupunkuncielemen dalammerek adalah nama merek, namun logo dan simboljuga merupakan suatu elemen yang diingat dalamingatan seseorang. Dengan demikian, penciptaan logo dan simbol sangat penting agar dapat dikaitkan dengan suatu nama merek didalam ingatan pelanggan.

Logo menjadi sebuah pengakuan, kebanggan, inspirasi kepercayaan, kehormatan, kesuksesan, loyalitas dan keunggulan yang tersirat ke dalam suatu bentuk atau gambar. Logo juga merupakan bagian yang penting untuk menunjukkan keberadaan suatu pembeda produk dengan produk lainnya. Logo diyakini dapat memberikan efek pengakuan tertentu kepada setiap orang yang melihat atau memakai. Perusahaan banyak melakukan perubahan logo agar lebih menarik dengan Rebranding.

Muzellec et al. (2003) menyatakan bahwa rebranding dalam suatu organisasi dapat berlangsung pada tingkat korporasi, tingkat unit bisnis, dan tingkat produk, yang paling kritis yang merupakan tingkat perusahaan yang mewakili identitas perusahaan secara keseluruhan.

Daly dan Moloney (2004) mempresentasikan sebuah kontinum rebranding terdiri dari tiga kategoriutama: perubahan kecil, perubahan menengah, dan perubahan lengkap. Lebih khusus lagi, rebranding dikategori- kan ke dalam jenis yang berbeda berdasarkan nama, logo dan slogan perubahan. Mungkin ada lima jenis rebranding: nama baru dan logo, nama baru, logo baru dan slogan, logo baru saja, dan hanya slogan baru. (Stuart dan Muzellec, 2004). Rebranding sebagai sebuah perubahan merek, seringkali identik dengan perubahan logo ataupun lambang sebuah merek. Dengan kata lain, ketika melakukan rebranding maka yang berubah ialah nilai-nilai dalam merek itu sendiri.

Rebranding memakan waktu yang lama karena harus mempertimbangkan beberapa faktor, diantaranya faktor internal dan eksternal. Faktor internal misalnya, perusahaan harus mempertimbangkan secara matang apakah perubahan inimembawa pengaruh yang besar bagi karyawannya dalam menjalankan tugasnya, karena karyawan harus memperkenalkan kembali logo baru tersebut ke masyarakat. Faktor eksternal ialah masyarakat dan stakeholder.

Perusahaan harus mempertimbangkan bahwa dengan perubahan logo, masyarakat memahami maksud dan tujuan yang hendak dicapai perusahaan. Untuk menciptakan brand sebuah perusahaan tidaklah mudah. Ada dua komponen penting yang perlu dipertimbangkan, yaitu tampilan dan bahasa.

Menurut (Mazwahid, 2012) tampilanberhubungan dengan logo bisnis atau produk. Sebuah logo yang efektif seharusnya: (1) Unik dan menarik bagi target market. (2) Mampu menggambarkan sifat alami bisnis produk, atau servis. Hal ini dapat ditafsirkan dengan dua cara yakni literal dan abstrak. (3) Tidak mudah usang/ketinggalan zaman karena pergantian waktu (tahan lama). (4) Dapat diterapkan dalam semua konteks potensi komunikasi.

Aspek yang sama pentingnya dalam membuat logo ialah bahasanya atau cara mengungkapkannya. Hal ini sering dijelaskan 
sebagai tagline atau cara memposisikan pernyataan untuk meyakinkan konsistensi dan kelanjutan darikedua hal yaitu penampilan dan bahasa yang menggambarkan perusahaan yang sekarang menjadi pelanggan. Identitas (termasuk logo) merupakan salah satu faktor penting yang mempengaruhi keberhasilan pembentukan citra merek.

Citra merek merupakan seperangkat keyakinan, ide, dan kesan yang dimiliki oleh seseorang terhadap suatu merek. Kotler mengatakan bahwa sikap dan tindakan konsumen terhadap suatu merek sangat ditentukan oleh citra merek tersebut (Simamora, 2006: 23).

Salah satu perusahaan BUMN yang pernah melakukan perubahan logo antara lain Telkom. Persainganbisnis telekomunikasiyang semakin ketat, menuntut pihak perusahaan penyedia layanan telekomunikasi untuk memikirkan kembali misi dan strategi bisnis yang baik, maka tidak menutup kemungkinan perusahaan tersebut akan kalah dalam persaingan. Menghadapi persaingan tersebut, setiap perusahaan memilkistrategitersendiriagar tetap eksis. Strategi manajemen perusahaan agar tetap eksis dan berkembang adalah dengan merubah identitas perusahaan dengan mengganti logo. Adapun perubahan logo Telkom dapat dilihat pada Gambar Logo PT Telkom Indonesia.

Memasuki Oktober 2009, Perusahaan Telekomunikasi Indonesia (PT Telkom Indonesia) resmimenggantilogonya dengan lambang yang menggambarkan lima jari tangan berwarna kuning yang melambangkan kelengkapan produk dan layanan serta pertumbuhan.

Selain logo baru Telkom juga merubah tagline yang tadinya Commited 2 You menjadi The World Is In Your Hand yang bermakna bahwainformasi di dunia ini dapat disatukan begitu dekat dan nyata dengan in- ternet, sehingga informasitersebut berada dalam genggaman tangan anda.

Alasan Telkom melakukan perubahan dikarenakan menyesuaikan dengan kondisi lingkungan yang ada, baik lingkungan, makro maupun mikro. Perkembangan teknologidan ketatnya industri teknologi komunikasi dan informasi di indonesia juga mendorong untuk melakukan perubahan.

Perubahan bisnis Telkom menyeluruh dan terintegrasi yang melibatkan empat aspek dasar perusahaan. Di antaranya adalah transformasi bisnis melalui penguatan bisnis inti (Fixed Wireline, Fixed Wireless Access dan penajaman portofolio bisnis); transformasi sistem dan modeloperasi melalui peningkatan kompetensi dan menumbuhkan layanan baru (new wave) seperti layanan berbasis broadband, enterprise, IT services, dan melakukan ekspansi bisnis media dan edutainment.

Dibidang teknologiTelkomjuga sudah melakukan transformasibesar-besaran dengan membangun jaringan berbasis teknologiNGN dengan konsep yang dikenal dengan nama INSYNC 2014. Transformasi organisasi dan sumber daya manusia juga dilakukan demi pencapaian sasaran organisasi yang semakin adaptif.

Telkom bergerak di bidang jasa teknologi, komunikasi daninformasi maka yang menjadi tujuan utama dari perusahaan adalah pencapaian kepuasaan pelanggan. Dalam bidang jasa kepuasan pelanggan sangat menentukan. Sekalipelanggan dikecewakan, maka persepsi dan citra suatu produk di mata pelanggan akan berkurang.

Berdasarkan pembahasan kajian teori dan penelitian terdahulu serta latar belakang permasalahan yang muncul, maka rumusan permasalahan yang diangkat dalam penelitian ini sebagai berikut: apakah perubahan logo (rebranding) berpengaruh terhadap citra 
merek pada PT Telkom Tbk diBandar Lampung. Sehingga tujuan penelitian ini untuk mengetahui pengaruh perubahan logo (rebranding) terhadap citra merek yang dilakukan oleh PT Telkom Tbk di Bandar Lampung.

Rebranding atau perubahan merek merupakan upaya yang dilakukan oleh perusahaan atau lembaga untuk mengubah total atau memperbaharui sebuah brand yang telah ada agar menjadi lebih baik, dengan tidak mengabaikan tujuan awal perusahaan, yaitu berorientasi profit. Rebranding sebagai sebuah perubahan merek, seringkali identik dengan perubahan logo ataupun lambang sebuah merek. Dengan kata lain, ketika melakukan rebranding maka yang berubah ialah nilai-nilai dalam merek itu sendiri.

Perubahan logo (rebranding) sendiri mempunyai langkah-langkah yaitu seperti gambar di atas definition-develop-designdeliver. Dengan adanya perubahan logo maka secara langsung dapat dilihat dari perbedaan bentuk atau desain logo, jenis huruf, warna, dan slogan/tagline yang berbeda dari logo sebelumnya. Menurut Shimp (2003:306)

Apapun bentuk logo yang dipilih maka logo tersebut harus mudah terlihat (eye catching) dan unik atau tampil beda, artinya ketika konsumen melihat logo tersebut maka ingatan konsumen akan langsung tertuju pada merek dan bukan kepada hal lain yang mungkin mirip atau serupa dengan merek yang divisualisasikan dalam logo. Jika logo tersebut mirip dengan logo kompetitor maka hal iniakan menimbulkan masalah. Dimana dalam hal ini konsumen justru akan lebih cenderung kepada merek kompetitor atau bahkan kompetitor akan memberikan tuduhan penjiplakan (Sarosa, 2006: 79-80).

Bentuk-bentuk logo yang patut dipertimbangkan dalammenvisualisasikan merek ke dalam logo adalah bentuk dan warna. Bentuk-bentuk logo di antaranya adalah: (1) Lo- go gram, desain logo jenis ini dibuat dari simbol atau bentuk-bentuk tertentu yang merepresentasikan nama dan citra perusahaan atau produk dan jasa yang ditawarkan. (2) Logo type, desain logo ini dibuat dari susunan huruf-huruf dengan jenis huruf sesuai citra perusahaan, produk, atau jasa yang ditawarkan. Huruf-huruf ini bisa berupa inisial atau ejaan lengkap dari nama perusahaan. (3) Logomixed, desain logo jenis ini logomixed merupakan gabungan dari simbol, bentuk, dan huruf yang disusun dengan memperhatikan citra, pandangan, dan tujuan perusahaan (Maria Regina College, 2009:66)

Citra konsumen yang positif terhadap suatu merek lebih memungkinkan konsumen untuk melakukan pembelian. Merek yang baik menjadi dasar untuk citra perusahaan yang postif. Menurut Kotler $(2005,629)$ citra atau image adalah seperangkat keyakinan, ide, dan kesan yang dimilki oleh seseorang terhadap suatu objek.

Citra (image) merupakan seperangkat keyakinan, gagasan, dan kesan yang dipakai oleh seseorang tentang sebuah obyek (Sulaksana, 2003:52). Pengertian citra itu sendiri abstrak atau intangible tetapi wujudnya dapat dirasakan dari hasil penilaian baik atau buruk. Sepertipenerimaan dan tanggapan baik positif maupun negatif.

\section{Metode Penelitian}

Berdasarkan perumusan masalah dan tujuan penelitian, jenis penelitian yang digunakan adalah jenis penelitian eksplanatori (explanatory research). Penelitian eksplantori adalah penelitian yang digunakan untuk menguji hipotesis tentang adanya hubungan variabel-variabel (sebab akibat). Dari definisi tersebut, alasan pemilihan model ini dimaksudkan untuk membuat penjelasan mengenai hubungan sebab akibat yang diper- 
oleh antar variabel yang diperoleh dengan fakta-fakta, sifat-sifat serta mengetahui seberapa kontribusi variabel-variabel bebas terhadap variabel terikatnya serta besar arah hubungan itu terjadi. Jadi penelitian yang dilakukan disiniadalah penelitian penjelasan untuk menguji pengaruh perubahan logo terhadap citra merek pada PT Telkom Tbk.

Adapun data yang dikumpulkan terdiri dari data primer dan data sekunder. Data primer merupakan data yang diperoleh secara langsung dari responden melalui wawancara dan pengamatan langsung dari sumber yang diteliti. Data primer antaralain berasal dari angket atau kuisioner yang disebarkan kepada responden. Data sekunder merupakan data yang bukan diusahakan sendiri pengumpulannya oleh peneliti. Dalam penelitian ini data sekunder diperoleh melalui pihak-pihak yang memberikan infomasi pendukung bagipenelitian, misalnya dari surat kabar, keterangan-keterangan atau publikasi dari internet.

Selanjutnya untuk melaksanakan penelitian ditentukan populasi untuk kemudian diambil sampel. Populasi menurut Suharsimi Arikunto (2002:108) merupakan keseluruhan subjek penelitian. Dalam penelitian kuantitatif, masalah yang sering dihadapi peneliti umumnya berkaitan dengan populasi yang diteliti. Populasi dalam penelitian ini adalah masyarakat di Bandar Lampung yang menggunakan jasa Telkom. Sampel adalah sebagian individu dari populasi yang diteliti, yang dipandang dapat menggambarkan secara representative mengenai keadaan populasi (Arikunto, 2002:109). Sampel diambil menggunakan metode non probability sampling dengan teknik purposive sampling. Teknik ini dilakukan karena karakteristik populasi tidak dapat diketahui dengan pasti dan konsumen diperkirakan homogen (Nazir, 2003: 332). Teknik ini dipilih oleh peneliti karena peneliti juga memiliki keterbatasan waktu dan dana. Pengambilan besarnya sampel menurut Roscoe 1975 (dalam Sekaran, 2003, Hair dkk, Tabachidan Fidell) yang dikutip oleh Augusty Ferdinand (2006:191), besarnya sampel yang ditentukan sebanyak 25 kali variabel independen. Sehingga, besarnya sampel dalam penelitian ini adalah 100 sampel perespon dari pengguna jasa PT Telkom Tbk di Bandar Lampung.

Data yang digunakan dalam penelitian ini adalah data primer, yang diperoleh secara langsung dari responden. Adapun teknik pengumpulan data yang digunakan pada penelitian ini: (1) Penelitian Pustaka (Library research), yaitu pengumpulan data teoritis dengan cara menelaah berbagai literatur dan bahan pustaka lainnya yang berkaitan dengan masalah yang diteliti. (2) Kuesioner berisi pernyataan yang bersifat tertutup dengan pilihan jawaban telah disediakan oleh peneliti dan disebarkan kepada konsumen. (3) Wawancara dan observasi. Hasil dari teknik ini dapat digunakan untuk melengkapi kuesioner bila ada pertanyaan yang belum terisi oleh responden.

Adapun variabel-variabel yang digunakan, yaitu variabel penelitian dan variabeloperasional. Variabel adalah gejala bervariasi yang menjadi objek penelitian. Menurut Arikunto (2002:101), bahwa variabel yang mempengaruhi disebut variabel penyebab, variabel bebas atau independent variabel (X), sedangkan variabel akibat disebut variabel tak bebas, variabel tergantung,variabel terikat atau dependent variabel (Y). Dalam penelitian ini yang merupakan variabel bebas adalah Perubahan logo $(\mathrm{X})$, sedangkan yang menjadi variabel terikat adalah Citra Merek (Y). Dalam penelitian ini variabel-variabel operasional yang akan diteliti yaitu: (1) variabel bebas atau independen variable (X): Perubahan Logo. (2) variabel terikat atau dependent variable: Citra Merek (Y) seperangkat keyakinan, ide atau gagasan dan kesan 
yang dimiliki oleh seseorang terhadap suatu objek. Citra merek konsumen dengan citra yang positif terhadap suatu merek, lebih memungkinkanuntuk melakukan pembelian. Perusahaan dapat mengembangkan lini produk dengan memanfaatkan citra yang positif yang telah terbentuk terhadap merek produk lama.

Indikator-indikator yang menjadi perubahan logo yaitu: (a) Perbedaan Bentuk: Perbedaan bentuk atau desain logo, lebih menarik dan mudah diingat, bentuk logo PT Telkom berupa kombinasi antara lingkaran dengan gambar jaritangan dan membentuk simbol matahari terbit. (b) Perbedaan jenis huruf: jelas untuk dibaca dan mudah dipahami. Jenis huruf menggunakan Font Sans Serif. (c) Pemberian Warna: Menonjolkan image dan mempunyai makna berbeda dari setiap warna. Warna logo terdiri dari warna $E x$ pert Blue pada teks Telkom, warna Vital Yellow pada telapak tangan, dan warna infinite sky blue pada teks Indonesia. (e) Pemberian slogan atau tagline: Mudah diucapkan dan mudah dimengerti, sloganlogo PT TelkomThe World in Your Hand, yang bermakna bahwa informasidi dunia ini dapat disatukan begitu dekat dan nyata dengan internet, sehingga informasi tersebut berada dalam genggaman tangan anda.

Adapunanalisis yang digunakan yaitu analisis kualitatif dan kuantitatif. Data yang diperoleh dari hasil penyebaran kuisioner selanjutnya diolah dan dianalisis dengan cara sebagai berikut: Data kualitatif yaitu data penelitian yang bukan angka, yang sifatnya tidak dapat dihitung berupa informasi atau penjelasan yang didasarkan pada pendekatan teoritis dan penilaian logis. Analisis kualitatif digunakan untuk memberikan gambaran secara deskriptif tentang tanggapan yang diberikan responden pada kuisoner atau daftar pertanyaan yang diberikan dan dihubungkan dengan teori pemasaran atau pendekatan-pen- dekatan yang berkaitan dengan pengaruh perubahan logo terhadap citra merek, melalui penilaian menggunakan skor dengan rumus rentang skor adalah skor tertinggi dikurangi skor terendah dibagi jumlah kelas (Umar, 2002).

$$
\mathrm{RS}=\frac{(\mathrm{m}-\mathrm{n})}{\mathrm{b}}
$$

Keterangan:

RS = Rentang Skor

$\mathrm{m}=$ Skor Tertinggi

$\mathrm{n}=$ Skor Terendah

$\mathrm{b}=$ Jumlah Kelas

Tabel 1. Kriteria Penilaian Konsumen

\begin{tabular}{ll}
\hline Kriteria & Skor \\
\hline $100-179$ & Sangat Tidak Baik \\
$180-259$ & Tidak Baik \\
$260-339$ & Cukup Baik \\
$340-419$ & Baik \\
$420-500$ & Sangat Baik \\
\hline
\end{tabular}

Analisis kuantitatif ini digunakan untuk mengetahui bagaimana penilaian konsumen tentang Pengaruh perubahan logo terhadap citra merek pada PT Telkom. Model analisis yang digunakan adalah Analisis Regresi Sederhana. Model Regresi digunakan untuk mengansumsikan bahwa terdapat hubungan linear antara variabel perubahan logo dan citra merek. Adapun bentuk umum persamaan analisis regresi sederhana yang digunakan dalam penelitian ini adalah sebagai berikut:

$$
\mathrm{Y}=\mathrm{a}+\mathrm{bX}+\mathrm{e}
$$

Keterangan:

$\mathrm{Y}=$ Citra Merek

a = Nilai konstanta

$\mathrm{X}=$ Perubahan Logo

e $=$ error

\section{Hasil Penelitian dan Pembahasan}

Uji validitas dilakukan dengan menggunakan analisis Pearson Product Moment de- 
Pengaruh Logo Baru PT. Telkom, Tbk... (Febriansyah, Nuzul I. N.)

ngan bantuan SPSS 13.0. Analisis dilakukan dengan cara mengkorelasikan masing-masing skor item dengan skor total. Skor total adalah penjumlahan dari keseluruhan item. Item-item pertanyaan yang berkorelasi signifikan dengan skor total menunjukkan itemitem tersebut mampu memberikan dukungan dalam mengungkapkan apa yang ingin $\mathrm{di}-$ ungkap.Valid atau tidaknya item pertanyaan dapat dilihat dari nilai koefisien korelasi setiap item dibandingkandengan skor total item pertanyaan.

Bila korelasi tiapitem tersebut positif dan besarnya 0,3 ke atas maka item pertanyaan tersebut akan membentuk variabel yang kuat dan valid (Barker, Pistrang \& Elliot, 2002: 70). Hasil yang diperoleh dari uji coba kuesioner kepada 30 responden menyatakan, bahwa pernyataan mengenai perubahan logo dan citra merek dinyatakan valid, dengan $\propto 0,05 \%$ dan tingkat kepercayaan sebesar $95 \%$ dengan $r$ hitung lebih besar dari 0,3 . Hasil pengujian validitas menunjukkan bahwa seluruh nilair hitung lebih besar daripada nilair-kritis 0,3 sehingga semua item pernyataan adalah valid.

Reliabilitas menyangkut ketepatan alat ukur. Reliabilitas atau keandalan suatu pengukuran merupakan indikasi adanya stabilitas ditunjukkan dengan kemampuan suatu pengukuran untuk tetap sama sepanjang waktu. Uji reabilitas menggunakan koefisien Alpha Croanbach dengan bantuan SPSS 13.0.
Pengujian reliabilitas dilakukan dengan beberapa tahapan yaitu dengan membandingkan nilai pada Croanbach Alpha dengan nilai pada Croanbach's Alpha if item deleted. Apabila ada pertanyaan memiliki nilai Croanbach's Alpha if item deleted lebih besar daripada Croanbach Alpha maka pertanyaan tersebut tidak reliabel dan harus dilakukan pengujian selanjutnya sehingga tidak ada lagi pertanyaan yang memiliki Croanbach's Alpha if item deleted yang lebih besar daripada Croanbach Alpha.

Ujireliabilitas dilakukan terhadap 30 responden pada tingkat kepercayaan $95 \%$ dan dilakukan dengan kriteria bahwa variabel penelitian yang memiliki nilai Cronbach Alpha's lebih besar daripada 0,7 (sekaran 2006) adalah reliabel.

Berdasarkan pengujian, diketahui bahwa variabel penelitian yang terdiri dari perubahan logo, dan citra merek memilikinilai alpha $0,748>0,7$ maka pernyataan tentang variabel perubahan logo dinyatakan reliabel, dan nilai alpha $0,805>0,7$.

Menjelaskan bahwa 47\% setuju logo PT Telkom lebih menarik dengan desain yang baru, desain yang berbentuk lima jari tangan dan berbeda dari logo lama yang hanya berbentuk lingkaran, dan 3\% tidak setuju desain logo yang lama lebih menarik. Halinimengidentifikasikan bahwa sebagian besar responden menyukai desain logo yang baru.

Tabel 2. Tanggapan Responden Bahwa Logo PT Telkom Terlihat Lebih Menarik Dengan Desain Yang Baru

\begin{tabular}{ccc}
\hline Skala Alternatif & Jumlah & Persentase \% \\
\hline Sangat Setuju & 45 & $45 \%$ \\
Setuju & 47 & $47 \%$ \\
Netral & 5 & $5 \%$ \\
Tidak Setuju & 3 & $3 \%$ \\
Sangat Tidak Setuju & 0 & $0 \%$ \\
Jumlah & 100 & $100 \%$ \\
\hline
\end{tabular}

Sumber: data diolah 
Ekonomika-Bisnis Vol. 5 No.2 Bulan Juli Tahun 2014. Hal 101-116

Tabel 3 menunjukkan bahwa responden setuju sebesar 54\% desain logo yang baru mudah diingat dibenak konsumen dengan desain logo berupa kombinasi antara lingkaran dengan gambar jari tangan dan membentuk simbol matahari terbit. Hal ini mengidentifikasikan bahwa sebagian besar responden lebih mudah mengingat logo yang baru dibandingkan dengan logo yang lama.

Tabel 4 menjelaskan hasil dari pernyataan logo baru PT Telkom jelas untuk diba- ca persentasenya sebesar $52 \%$ setuju dan sangat setuju sebesar $36 \%$ dengan adanya huruf yang melambangkan Telkom Indonesia dan memakaijenis hurufmenggunakan Font Sans Serif.

Pada tabel 5, terlihat bahwa huruf pada logo baru yang bertuliskan Telkom Indonesia memakai jenis huruf Font Sans Serif mudahdipahami denganjelas, responden menjawab setuju sebanyak $47 \%$, sangat setuju sebanyak $29 \%$, netral $22 \%$ dan tidak setuju

Tabel 3. Tanggapan Responden Bahwa Desain Logo Mudah Diingat Dibenak Konsumen

\begin{tabular}{ccc}
\hline Skala Alternatif & Jumlah & Persentase \% \\
\hline Sangat Setuju & 27 & $27 \%$ \\
Setuju & 54 & $54 \%$ \\
Netral & 14 & $14 \%$ \\
Tidak Setuju & 5 & $5 \%$ \\
Sangat Tidak Setuju & 0 & $0 \%$ \\
Jumlah & 100 & $100 \%$ \\
\hline
\end{tabular}

Sumber: data diolah

Tabel 4. Tanggapan Responden Bahwa Logo Baru PT Telkom Jelas Untuk Dibaca

\begin{tabular}{ccc}
\hline Skala Alternatif & Jumlah & Persentase \% \\
\hline Sangat Setuju & 36 & $36 \%$ \\
Setuju & 52 & $52 \%$ \\
Netral & 11 & $11 \%$ \\
Tidak Setuju & 1 & $1 \%$ \\
Sangat Tidak Setuju & 0 & $0 \%$ \\
Jumlah & 100 & $100 \%$ \\
\hline
\end{tabular}

Sumber: data diolah

Tabel 5. Tanggapan Responden Bahwa Huruf Atau Tulisan Pada Logo Mudah Dipahami

\begin{tabular}{ccc}
\hline Skala Alternatif & Jumlah & Persentase \% \\
\hline Sangat Setuju & 29 & $29 \%$ \\
Setuju & 47 & $47 \%$ \\
Netral & 22 & $22 \%$ \\
Tidak Setuju & 2 & $2 \%$ \\
Sangat Tidak Setuju & 0 & $0 \%$ \\
Jumlah & 100 & $100 \%$ \\
\hline
\end{tabular}

Sumber: data diolah 
Pengaruh Logo Baru PT. Telkom, Tbk... (Febriansyah, Nuzul I. N.)

sebanyak $1 \%$. Halinimengidentifikasikan bahwa sebagian besar setuju tulisan dan huruf logo Telkom mudah dipahami.

Tabel 6 menjelaskan hasil dari pernyataan warna logo baru PT Telkom lebih terang (eye catching) warna logo yang terdiri dari; warna Expert Blue pada teks Telkom, warna Vital Yellow pada telapak tangan, warna Infinite sky blue pada teks Indonesia. Memperlihatkan hasil jawaban responden yaitu $48 \%$ menjawab setuju, $41 \%$ menjawab sangat setuju, $10 \%$ menjawab netral terhadap warna logo yang baru dan $1 \%$ menjawab tidak setuju terhadap warna logo yang baru lebih eye catching. Hal ini mengidentifikasikan sebagian besar responden setuju warna logo baru PT Telkom lebih terang dari logo lama.

Tabel 7 menjelaskan logo mempunyai makna yang berbeda dari setiap warna. $E x$ - pert Blue pada teks Telkom melambangkan keahlian dan pengalaman yang tinggi Vital Yellow pada telapak tangan mencerminkan suatu yang atraktif, hangat, dan dinamis Infinite sky blue pada teks Indonesia dan lingkaran bawah mencerminkan inovasi dan peluang yang tak berhingga untuk masa depan. Memperlihatkan hasil jawaban kuisioner dengan presentase sangat setuju $19 \%$, setuju $44 \%$, netral $36 \%$, dan tidak setuju sebesar $1 \%$. Hal ini mengidentifikasikan bahwa sebagian besar responden mengetahui makna warna pada logo Telkom.

Tabel 8 menunjukkan bahwa sebagian responden setuju sloganPT Telkommudah diucapkan the world is in your hand dengan persentase sebesar 46\%. Sedangkan beberapa responden menyatakan bahwa slogan sulit untuk diucapkan dengan presentase sebe-

Tabel 6. Tanggapan Responden Bahwa Warna Logo Baru PT Telkom Lebih Terang (Eye Catching)

\begin{tabular}{ccc}
\hline Skala Alternatif & Jumlah & Persentase \% \\
\hline Sangat Setuju & 41 & $41 \%$ \\
Setuju & 48 & $48 \%$ \\
Netral & 10 & $10 \%$ \\
Tidak Setuju & 1 & $1 \%$ \\
Sangat Tidak Setuju & 0 & $0 \%$ \\
Jumlah & 100 & $100 \%$ \\
\hline
\end{tabular}

Sumber: data diolah

Tabel 7. Tanggapan Responden Bahwa Logo Mempunyai Makna Yang Berbeda dari Setiap Warna

\begin{tabular}{ccc}
\hline Skala Alternatif & Jumlah & Persentase \% \\
\hline Sangat Setuju & 19 & $19 \%$ \\
Setuju & 44 & $44 \%$ \\
Netral & 36 & $36 \%$ \\
Tidak Setuju & 1 & $1 \%$ \\
Sangat Tidak Setuju & 0 & $0 \%$ \\
Jumlah & 100 & $100 \%$
\end{tabular}

Sumber: diolah 
sar 9\% karena lebih menyukai slogan lama yang sudah melekat di benak konsumen Commited 2 you.

Tabel9 menjelaskan bahwa sebagian respoden dengan persentase $53 \%$ mengetahui slogan PT Telkom mudah dimengerti maksud dan tujuannya the world is in your hand yang bermakna bahwa informasi di dunia ini dapat disatukan begitu dekat dan nyata dengan internet, sehingga informasitersebut berada dalam genggaman tangan anda, dan $9 \%$ menyatakan tidak setuju karena sulit untuk dipahami lebih menyukai slogan logo yang lama yaitu Commited 2 you, dan sebagian responden netral terhadap slogan yang baru presentase sebesar $25 \%$.

Dapat disimpulkan bahwa perubahan logo PT Telkom dipersepsikan oleh para responden memiliki desain yang menarik dinilai sangat baik, bentuk logo atau desain logo mudah diingat dinilai baik, logo jelas dibaca dinilai sangat baik, logo mudah dipahami dinilai baik, warna logo lebih terang (eye catching) dinilai sangat baik, logo mempunyai makna yang berbeda dari setiap warna dinilaibaik, dan slogan mudah diucapkan serta slogan mudah dipahami dinilai responden baik.

Dari tabel 10 terlihat bahwa logo PT Telkom lebih menarik dengan desain yang baru memiliki skor tertinggi sebesar 434, sedangkan skor terendah 365 dinilai baik oleh responden dengan item pertanyaan slogan mudah diucapkan The world is in your hand. Hal ini mengidentifikasikan slogan baru belum dikenal oleh konsumen dan sulit untuk mengucapkannya karena slogan lama masih melekat di benak konsumen dengan slogan Commited 2 you.

Tabel 11 menjelaskan bahwa sebagian responden sebesar $57 \%$ setuju logo baru mem-

Tabel 8. Tanggapan Responden Bahwa Slogan PT Telkom Mudah Diucapkan The world Is In Your Hand

\begin{tabular}{ccc}
\hline Skala Alternatif & Jumlah & Persentase \% \\
\hline Sangat Setuju & 15 & $15 \%$ \\
Setuju & 46 & $46 \%$ \\
Netral & 29 & $29 \%$ \\
Tidak Setuju & 9 & $9 \%$ \\
Sangat Tidak Setuju & 1 & $1 \%$ \\
Jumlah & 100 & $100 \%$ \\
\hline
\end{tabular}

Sumber: data diolah

Tabel 9. Tanggapan Responden bahwa slogan Telkom mudah dimengerti maksud dan tujuannya

\begin{tabular}{ccc}
\hline Skala Alternatif & Jumlah & Persentase \% \\
\hline Sangat Setuju & 13 & $13 \%$ \\
Setuju & 53 & $53 \%$ \\
Netral & 25 & $25 \%$ \\
Tidak Setuju & 9 & $9 \%$ \\
Sangat Tidak Setuju & 0 & $0 \%$ \\
Jumlah & 100 & $100 \%$ \\
\hline
\end{tabular}

Sumber: data diolah 
Pengaruh Logo Baru PT. Telkom, Tbk... (Febriansyah, Nuzul I. N.)

buat kesan citra Telkom lebih baik, $24 \%$ sangat setuju logo baru lebih baik, $16 \%$ netral terhadap logo yang baru dan $3 \%$ responden tidak setuju dengan kesan yang diberikan logo baru. Hal ini mengidentifikasikan responden setuju adanya perubahan logo pada PT Telkom dan membuat kesan yang lebih baik tidak ketinggalan zaman sertamemilikicitra yang baik dibenak konsumen.

Tabel 12 menjelaskan bahwa sebagian responden sebesar $47 \%$ setuju menyatakan logo baru Telkom dapat menambah kepercayaan konsumen, persentase netral sebesar 32\% dikarenakan sebagian responden merasakan tidak berpengaruh dengan adanya logo baru yang dapat menambah kepercayaan konsumen, dan $8 \%$ tidak setuju adanya logo baru Telkom yang dapat menambah kepercayaan konsumen.

Tabel 13 mengindikasikan bahwa sebagian responden sebesar $53 \%$ setuju logo baru menambah gagasan perubahan terha-

Tabel 10. Skor Keseluruhan Variabel Perubahan Logo (X)

\begin{tabular}{|c|c|c|c|}
\hline No & Item Pertanyaan & Skor & Kriteria \\
\hline 1 & $\begin{array}{l}\text { Logo PT Telkom terlihat lebih menarik dengan } \\
\text { desain yang baru }\end{array}$ & 434 & $\begin{array}{c}\text { Sangat } \\
\text { Baik }\end{array}$ \\
\hline & Bentuk logo atau desain logo mudah diingat dibenak & 403 & \\
\hline 2 & & 423 & $\begin{array}{c}\text { Baik } \\
\text { Sangat }\end{array}$ \\
\hline 3 & Logo PT Telkom jelas untuk dibaca & & Baik \\
\hline 4 & Tulisan pada logo mudah dipahami & 403 & Baik \\
\hline 5 & $\begin{array}{l}\text { Warna logo baru PT Telkom lebih terang (eye } \\
\text { catching) }\end{array}$ & 429 & $\begin{array}{c}\text { Sangat } \\
\text { Baik }\end{array}$ \\
\hline 6 & $\begin{array}{l}\text { Logo PT Telkom mempunyai makna yang berbeda } \\
\text { dari setiap warna }\end{array}$ & 381 & Baik \\
\hline 7 & Slogan mudah diucapkan The world is in your hand & 365 & Baik \\
\hline \multirow[t]{2}{*}{8} & $\begin{array}{l}\text { Slogan PT Telkom mudah dimengerti maksud dan } \\
\text { tujuannya. }\end{array}$ & 370 & Baik \\
\hline & Rata-rata & 401 & Baik \\
\hline
\end{tabular}

Sumber: data diolah dari lampiran 3

Tabel 11. Tanggapan Responden Bahwa Perubahan Logo Membuat Kesan Citra PT Telkom Lebih Baik

\begin{tabular}{ccc}
\hline Skala Alternatif & Jumlah & Persentase \% \\
\hline Sangat Setuju & 24 & $24 \%$ \\
Setuju & 57 & $57 \%$ \\
Netral & 16 & $16 \%$ \\
Tidak Setuju & 3 & $3 \%$ \\
Sangat Tidak Setuju & 0 & $0 \%$ \\
Jumlah & 100 & $100 \%$ \\
\hline
\end{tabular}

Sumber: data diolah 
dap Telkom, responden melihat gagasan atau ide yang baru diberikan Telkom terlihat jelas dengan adanya transformasi bisnis, dan 3\% tidak setuju logo baru menambah gagasan dikarenakan responden tidak mencari informasi yang diberikan Telkom.

Dari Tabel 14 Dapat disimpulkan bahwa citra merek pada PT Telkom setelah melakukan perubahan logo, dipersepsikan oleh responden menyukai logo yang baru dengan kesan yang baik memiliki skor tertinggi 402 , karena logo lama sudah tidak update atau ketinggalanzaman, sedangkan skor terendah 365 dinilai baik dengan pertanyaan logo baru dapat menambah kepercayaan konsumen pada PT Telkom dirasakan konsumen tidak memberikan dampak yang positif karena pelanggan PTTelkom tidak melihat dari sisi logonya, pelanggan melihat dari sisi pelayanan yang diberikan Telkom kepada konsumen.
Skor 370 dengan pertanyaan menambah gagasan perubahan Telkom di mata konsumen dinilai cukup baik, hal ini seiring dengan PT Telkom merubah transformasi bisnis secara menyeluruh dan terintegerasi. Diharapkan responden dengan adanya logo baru, maka Telkom dapat meningkatkan kepercayaan yang dijanjikan oleh Telkom dan berusaha menyediakan apa yang dibutuhkan konsumen.

Secarakeseluruhan perubahan $\log 0(r e-$ branding) terhadap citra merek pada PT Telkom TbkdiBandar Lampung sudahdinilaibaik dengan skor rata-rata untuk kedua variabel sebesar 390. Dapat dilihat bahwa perubahan logo dinilai baik dengan skor 401 sedangkan citra merek dinilai baik oleh responden. Hal ini didukung darikarakteristik responden usia 21-25 tahun yaitu mahasiswa maupun lulusan sarjana mayoritas pengguna telepon rumah maupun telepon seluler, responden menyukai

Tabel 12. Tanggapan Responden Bahwa Logo Baru Dapat Menambah Kepercayaan Konsumen Pada PT Telkom

\begin{tabular}{ccc}
\hline Skala Alternatif & Jumlah & Persentase \% \\
\hline Sangat Setuju & 13 & $13 \%$ \\
Setuju & 47 & $47 \%$ \\
Netral & 32 & $32 \%$ \\
Tidak Setuju & 8 & $8 \%$ \\
Sangat Tidak Setuju & 0 & $0 \%$ \\
Jumlah & 100 & $100 \%$ \\
\hline
\end{tabular}

Sumber: data diolah dari lampiran 3

Tabel 13. Tanggapan responden bahwa logo baru menambah gagasan perubahan terhadap PT Telkom

\begin{tabular}{ccc}
\hline Skala Alternatif & Jumlah & Persentase \% \\
\hline Sangat Setuju & 10 & $10 \%$ \\
Setuju & 53 & $53 \%$ \\
Netral & 34 & $34 \%$ \\
Tidak Setuju & 3 & $3 \%$ \\
Sangat Tidak Setuju & 0 & $0 \%$ \\
Jumlah & 100 & $100 \%$ \\
\hline
\end{tabular}

Sumber: data diolah 
Pengaruh Logo Baru PT. Telkom, Tbk... (Febriansyah, Nuzul I. N.)

perubahaan desain,warna, huruf, dan slogan logo yang baru terlihat lebih update dengan transformasi bisnis baru pada PT Telkom.

Untuk mengetahui pengaruh perubahan logo (rebranding) terhadap citra merek pada PT Telkom Tbk di Bandar Lampung digunakan analisis regresi sederhana yang perhitungannya dilakukan dengan program SPSS versi 13.0.

Berdasarkan hasilpenelitian maka diperoleh pengaruh perubahan logo terhadap citra merek $\left(\mathrm{r}^{2}\right)$ sebesar 0,235 hal ini berarti sumbangan variabel $\mathrm{x}$ (perubahan logo) berperan dalam mempengaruhi setiap penambahan variabely citra merek $23,5 \%$ dan $76,5 \%$ sisanya dipengaruhi oleh faktor lain. Pengaruh perubahan logo dinilaimemberikan kontribusi yang kecil terhadap citra merek, karena logo yang baru belum dikenal olehpara konsumen. Persaman RegresiLinier Sederhana yang diperoleh adalah:

$$
\mathrm{Y}=2,858+0,485 \mathrm{x}
$$

Pengujian regresi diatas dilakukan pada taraf signifkan 95\% ( $\alpha=5 \%)$ Nilai $\alpha$ persamaan regresi bernilai positif 0,485 . Hal ini membuktikan bahwa perubahan logo memberi pengaruh positif terhadap citra merek.

Selanjutnya dilakukan pengujian hipotesis untuk mengetahui signifikansi pengaruh perubahan logo terhadap citra merek dengan menggunakan uji t, yaitu membandingkan nilai $\mathrm{t}_{\text {hitung }}$ dengan $\mathrm{t}_{\text {tabel }}$ pada taraf signifikan $95 \%$ atau dengan $\alpha 0,05$ serta menggunakan derajat kebebasan df (degree freedom). $\mathrm{Df}=\mathrm{n}-\mathrm{k}-1=100-1-1=98$, Diperoleh nilai t Tabel $(0,05 ; 98)=1,984$ Ketentuannya adalah jika $t_{\text {hitung }}>t_{\text {tabel }}$ maka ada signifikansi, sebaliknya jika $\mathrm{t}_{\text {hitung }}<\mathrm{t}_{\text {tabel }}$ maka tidak ada signifikansi.

Hasil pengujian hipotesis pengaruh perubahan logo terhadap citra merek dengan uji t dapat dilihat pada hasil uji t pada tabel 16.

Tabel 14. Skor Keseluruhan Variabel Citra Merek (Y)

\begin{tabular}{cccc}
\hline No & Item Pernyataan & Skor & Kriteria \\
\hline \multicolumn{3}{c}{$\begin{array}{c}\text { Perubahan logo membuat kesan citra PT } \\
\text { Telkom lebih baik }\end{array}$} & Baik \\
\hline & $\begin{array}{c}\text { Logo baru dapat menambah kepercayaan } \\
\text { konsumen pada PT Telkom }\end{array}$ & & \\
2 & Logo baru menambah gagasan perubahan \\
terhadap PT Telkom & 365 & Baik \\
3 & Rata-rata & 370 & Baik \\
& & 379 & Baik
\end{tabular}

Sumber: data diolah

Tabel 15. Rekapitulasi Hasil Skor Dua Variabel Perubahan logo dan Citra Merek

\begin{tabular}{cccc}
\hline No & Variabel & Total Skor & Kriteria \\
\hline 1 & Perubahan logo & 401 & Baik \\
2 & Citra Merek & 379 & Baik \\
3 & Total skor rata-rata & 390 & Baik
\end{tabular}

Sumber: data diolah 
Berdasarkan tabel 16, maka besarnya nilai $t_{\text {hitung }}$ adalah 5,486 dan $\mathrm{t}_{\text {tabel }}$ pada tingkat signifikan 95\% adalah 1.984 yang artinya perbandingan $\mathrm{t}_{\text {hitung }}$ dengan $\mathrm{t}_{\text {tabel }}$ adalah $5,486>1.984$ atau $\mathrm{t}_{\text {hitung }}$ lebih besar dari $\mathrm{t}_{\text {tabel }}$ pada taraf signifikan $95 \%$. Dengan demikian maka hipotesis penelitian diterima, artinya perubahan logo (rebranding) berpengaruh secara signifikan terhadap citra merek pada PT Telkom Tbk diBandar Lampung.

\section{Penutup}

Berdasarkan hasil analisis dan pembahasan tentang pengaruh perubahan logo (rebranding) terhadap citra merek pada PT Telkom di Bandar Lampung, maka dapat disimpulkan sebagai berikut: (1) Pengaruh perubahan logo terhadap citra merek sebesar $r^{2}=0,235$. Hal ini berarti sumbangan variabel $x$ (Perubahan logo) berperan dalam mempengaruhi setiap penambahan variabel y (Citra Merek) sebesar 23,5\%. Hal ini menunjukkan bahwa perubahan logo PT Telkom memberi pengaruh yang kecil terhadap citra merek. (2) Pengujian Hipotesis menunjukan bahwa $\mathrm{t}_{\text {hitung }}$ lebih besar dari $\mathrm{t}_{\text {tabel }}$ yaitu $5,486>1.984$ artinya perubahan logo (rebranding) berpengaruh secara signifikan terhadap citra merek pada PT Telkom di BandarLampung, semakin melekat logo di benak konsumen dengan desain, warna, huruf dan slogan maka citramerek akan berpengaruh positif dibenak konsumen. (3) Dari data kualitatif dilihat dari skor rata-rata bahwa item pertanya- an tentang logo Telkom terlihat lebih menarik dengan desain yang baru memiliki skor tertinggi sebesar 434, sedangkan skor terendah slogan sulit untuk diucapkan The World Is In Your Hand memiliki skor 365. Hal ini disebabkan slogan baru belum dikenal secara luas, dan slogan lama Telkom Commited 2 You masih melekat di benak konsumen. (4) Hasil analisis kualitatif menyatakan bahwa dari 2 variabel yang terdiri dari 11 item pertanyaan, sebanyak 3 item pernyataan dinilai sangat baik dengan item pertanyaan logo terlihat lebih menarik dengan desain yang baru, logo Telkomjelas untuk dibaca, dan warnalogo baru terlihat lebih terang atau eye catching. dan sisanya sebanyak 8 item pertanyaan dinilai baik olehresponden. (5) Serta dapat dilihat dari rekapitulasi skor rata-rata dua variabel, bahwa variabel perubahan logo dinilai baik dan varibel citra merek dinilai baik. Jadi keseluruhan perubahan logo (rebranding) terhadap PT Telkom Tbk di Bandar Lampung sudah dinilai responden baik dengan skor ratarata untuk kedua variabel sebesar 390.

Berdasarkan pembahasan dan kesimpulan dari hasil penelitian, mengenai pengaruh perubahan logo (rebranding) terhadap citra merek pada PT Telkom Tbk diBandar Lampung maka saran yang dapat diberikan oleh peneliti antara lain:

Pertama, dari data kualitatif di atas nilai tertinggi dapat dilihat dari skor rata-rata bahwa item pertanyaan tentang logo Telkom terlihat lebih menarik dengan desain yang baru.

Tabel 16. Hasil Uji Signifikansi

\begin{tabular}{cccc} 
Variabel & $\mathrm{t}_{\text {hitung }}$ & $\begin{array}{c}\mathrm{t}_{\text {tabel }} \text { pada tingkat } \\
\text { kepercayaan } 95 \%\end{array}$ & Kesimpulan \\
\hline $\mathrm{X}$ terhadap Y & 5,486 & 1.984 & $\begin{array}{c}\text { Ada pengaruh } \\
\text { signifikan }\end{array}$
\end{tabular}

Sumber: Data diolah 
Pengaruh Logo Baru PT. Telkom, Tbk... (Febriansyah, Nuzul I. N.)

Hal ini menjelaskan bahwa responden menyukai perubahan bahkan melakukan perubahan logo (rebrand) menjadi topik yang semakin menarik mengingat banyak perusahaan yang melakukan rebrand terutama logo produk maupun logo perusahaannya, dan terdapat suatu forumyang disebut rebrand.com yang mengadakan kompetisi di seluruh dunia untuk perubahan terbaik setiap tahun.

Kedua, sebaiknya perusahaan memberikan promosi secara aktif melalui iklan, media cetak, baliho maupun reklame agar konsumen mengetahui Telkommelakukan rebranding dengan slogan baru The World Is In Your Hand, dengan cara mengingatkan pelanggan melalui promosi yang efektif maka Telkom akan lebih dikenal oleh konsumen dengan logo dan slogan yang baru dan menjadi sebuah gagasan atau ide yang membuat citra perusahaan Telkom semakin membaik, dan pelanggan tidak memilih layanan ke produk lainnya.

\section{DAFTAR PUSTAKA}

Alshebil, Saleh AbdulAziz. 2007. Consumer Perception of Rebranding: The Case of Logo Changes. The University of Texas. Arlington.

Arikunto, Suharsimi. 2002. Prosedur Penelitian Suatu Pendekatan Praktek. Penerbit Rineka Cipta. Jakarta.

Ferrinadewi, Erna. 2008. Merek dan Psikologi Konsumen. Graha ilmu. Yogyakarta.

Kertajaya, Hermawan. 2007. Herwaman Kertajaya on brand. PT Mizan Pustaka. Bandung.

Kotler, Philip. 2005. Dasar-dasar Pemasaran (Jilid 2). Indeks Media Gramedia. Jakarta.
Kotler, Philip. 2009. Manajemen Pemasaran. Prenhalido. Jakarta.

Nazir, Mohammad. 2003. Metodologi Penelitian. Ghalia Indonesia. Jakarta.

Rangkuti, Freddy. 2004. The Power of Brands. PT. Gramedia Pustaka Utama. Jakarta.

Sekaran, U. 2006. Research Method For Business: Metodologi Penelitian Untuk Bisnis. Salemba Empat. Jakarta.

Shimp, Terence, A. 2003. Periklanan Promosi Aspek Tambahan Komunikasi Pemasaran Terpadu. Alihbahasa: RevyaniSyahrial danDyah Anikasari.Erlangga. Jakarta.

Soomro, Yasir Ali; Shakoor, Rehan. 2011. Impact of Logo on Consumer Perception of a Company. Interdiscipline Journal of Contemporary Research in Business. Vol3. No.7. Page 194-201.

Sutisna. 2001. Perilaku konsumen dan Komunikasi Pemasaran. Penerbit Remaja Rosda Karya. Bandung.

Tjiptono, Fandy. 2005. Brand Management \&Strategy. Penerbit Andi. Yogyakarta.

UU Merek No.15 Tahun 2001 pasal 1 ayat 1.

Umar, Husein. 2002. Riset Pemasaran dan Perilaku Konsumen. Gramedia Pustaka Utama. Jakarta.

Umar, Husein. 2002. Metode Penelitian dalam Aplikasi Pemasaran. PT Gramedia Pustaka Utama. Jakarta. 
